\title{
Assessing Urban Growth Dynamics and Depletion of Agricultural Land Use in Akure Region, Nigeria
}

\author{
J.O. Owoeye ${ }^{1}$ \\ ${ }^{1}$ Department of Urban and Regional Planning, School of Environmental Technology, Federal University of \\ Technology, Akure, Nigeria \\ Correspondence: J.O. Owoeye, Department of Urban and Regional Planning, School of Environmental \\ Technology, Federal University of Technology, PMB 704, Akure Ondo State, Nigeria. Tel: 234-0803-917-9250. \\ E-mail: joowoeye@futa.edu.ng
}

Received: November 2, 2019 Accepted: December 19, 2019 Published: December 26, 2019

The research was financed by the Management of the Federal University of Technology, Akure under Staff Development Scheme and TET-Fund sponsored PhD Split-site Research Training Program at the University of the West of England, Bristol United Kingdom.

\begin{abstract}
This study examined the Akure urban growth dynamics and the impact on agricultural land use in the region between 1985 and 2014. It makes use of Aerial Imagery Interpolation (AII) of Landsat imagery of 1986, 2002, 2007 and 2014 to determine LULC change pattern, the extent and direction of the expansion. As at 1986, only $5.1 \%$ (6384 ha.) of land area was developed while over $90 \%$ were covered with thick (64.5\%) and light (30.33\%) vegetation which were lands used for agricultural purposes. By 2014, the built-up area had increased to $26.33 \%$ while the thick vegetation reduced drastically to $15.6 \%$. Further investigation revealed that the growth dynamics and loss of agricultural land use in the region were products of increased population and continued urbanization process. There were incompatible conversions in LULC and unguided expansions leading to undue encroachment into green areas at the suburbs. With the aid of Markov chain model, the trend was predicted over a period of 20 years (2014-2034). Variability in this relationship suggests the need of concerted urban growth management efforts by different stakeholders in urban planning to check the shoddy expansion with a view to securing agricultural lands for sustainable food security in the region.
\end{abstract}

Keywords: assessing, growth dynamics, agricultural land-use, Akure region, Markov chain model

\section{Introduction}

Several studies have linked Land Use and Land Cover (LULC) change with urbanization, as a phenomenon prompted by many factors like human activities, culture, economy, policy making, planning and environment (Houghton, 1994; Chellasamy et al., 2015; Mirkatouli et al., 2015; Gumma, 2017). Rapid pace of urbanization is believed to be a global problem, which has led to dramatic change in urban landscapes and other land use practices; particularly, as it escalates pressure on agricultural land use, leading to loss of biodiversity, competition on forest and other land resources. Depletion of agricultural lands is one of the major factors affecting food security in many cities of the world. Kaifang et al. (2016) opined that substantial area of agricultural land; including cropland, forest, and grassland have been converted into artificial or impervious surfaces. Thus, a study on investigation of agricultural land loss due to urban expansion is crucial to sustainable food security. Globally, land cover is frequently altered principally by direct human use such as agriculture and livestock raising, forest harvesting and management, urban and sub-urban construction and development (Chen et al., 2013; Mirkatouli et al., 2015). From the perception of Kufoniyi (1998), Olofin (2012), Rimal (2013), and Oduwaye (2015), there is hardly can we find any vegetation that has not been affected or altered by man in the world. In this regard, about 400,000 hectares of vegetation cover are confirmed to be lost annually (Adesina et al., 1999; Balogun et al., 2011; Oduwaye, 2015).

Unguided expansion and uncontrolled population growth cause serious problems, especially, in developing countries. It harms the environment and causes environmental pollution, informal settlements, and food paucity as most agricultural lands are lost to several developments in the cities. It also contributes to the destruction of ecological structure. Balogun et al (2011) observed 40\% growth of urban populations in developing countries between 1900 and 1975. Globally, the rapid urbanization of the world's population over the twentieth century has 
being tremendous as the global proportion of urban population rose dramatically from 13\% (220 million) in 1900 to $29 \%$ (732 million) in 1950 and to $49 \%$ in 2005. Presently, about $55 \%$ live in cities while $60 \%$ (4.9billion) is being projected for year 2030 (UN Report, 2018). The growth of Akure is similar to this appraisal as the population has inflated more than triple of what it was before it emerged the state capital in 1976. Presently, the estimated population is over 500000 compared with 71106 in 1963, 239124 in 1991 and 360268 in 2006 (NPC, 1963, 1991 and 2006) and estimated growth of 476159 in 2014 (when the study was conducted). This, in no doubt, has influenced the spatial expansion of the city and as well increased the rate of land consumption in the region.

As revealed in literatures, uncoordinated urban expansion and unplanned LULC change constitute major problem to city planners. Most changes that occur are without clear and logical planning that gives consideration to environmental impacts (Chellasamy et al., 2015; Balogun et al., 2011). For instance, major flooding and air pollution in large cities as well as deforestation, urban growth, soil erosion, and desertification, are all consequences of a mismanaged planning and inappropriate projects' execution without giving adequate consideration to their impacts on the environment (Chellasamy et al, 2015; Owoeye, 2016). These studies observed that rapid land use changes occasioned by rising population have reduced natural vegetation cover leading to massive depletion of agricultural land use; principally, at the suburbs.

Unguided urban growth and frequent land use changes arising from swelling housing development and massive deforestation are notable contributing factors to land cover change and depletion of farmlands in Akure and its environs. These changes reflect on the population growth, land consumption rate and local climate variation. The expansion of Akure has not only resulted in depletion of land cover and other natural resources, but also in deterioration of the environment due to incompatible changes in land use pattern. Agriculturally productive land and forestland are being converted to residential and other uses. According to Balogun et al. (2011), the pattern of land use and land cover in a region is an outcome of natural and socio-economic factors and their utilization by man in time and space. Thus, the uncontrolled population growth and physical development in Akure are products of various anthropogenic and man's innate factors which have adversely affected his ecosystem with indirect consequences on the local climate modification (Akinbode et al., 2007; Balogun et al., 2009). Apparently, this and other human-induced factors, affect agricultural activities in the region. The thrust of this study, however, is to assess the urban growth dynamics of Akure and its impact on agricultural land use in the region between 1985 and 2014 with a view to providing information that will aid policy formulation towards the physical planning and sustainable agricultural land use in the region.

\section{Method}

\subsection{The Research Location}

This study focuses on Akure region, which involve three local government areas (LGAs) - Akure South, Akure North and Ifedore LGAs - as shown in Figure 1. Akure is a notable city in the South-western Nigeria which became the capital of Ondo State on February $3^{\text {rd }} 1976$. Located between Latitudes $7^{0} 15^{1}$ and $7^{0} 17^{1}$ North and between Longitudes $5^{0} 14^{1}$ and $5^{0} 15^{1}$ East, it is about $311 \mathrm{~km}$ north-east of Lagos and $323 \mathrm{~km}$ south-west of Abuja (the Federal Capital Territory of Nigeria). Akure town spreads over an area of about $15,500 \mathrm{~km}^{2}$ in about $370 \mathrm{~m}$ above the sea level. Its population figure by the National Population Census (NPC, 1963) was just 71106; but with the increasing influx of public servants into the town consequent upon the state creation in 1976, the population rose to 239,124 and 360,268 in 1991 and 2006 respectively (NPC, 1991 and 2006). The projected population figure in 2014 (when the study was conducted) was 476,159. Currently, the population is over 500,000 inhabitants.

\subsection{Research Database}

Data collection for this study was essentially through Aerial Imagery Interpolation (AII) with the aid of GIS and RS devises. It also makes use of personal observations and photo-snaps to capture changes in the physical landscape of the study area. Other sources include government ministries and establishments for the base map and population data used for the study. Internet facilities were equally explored to give additional information relevant to the study. The study adopts the 2014 projected population of 476,159 with a total land expanse of 125,212 hectares which were used in the analysis. The main approach used in the study was post-classification comparative analysis of satellite imageries of Akure obtained at different period; specifically, 1986, 2002, 2007 and 2014. This helps to show the direction and extent of growth in the study area from one period to the other wherein the dynamism in the growth was distinctly assessed. The land use for the study area is classified into four categories and displayed in colours for clear picturing. They include built-up area (involving residential, commercial, industrial, recreational and educational land uses), thick vegetation (forested land areas), light vegetation, and water bodies (rivers and streams). 


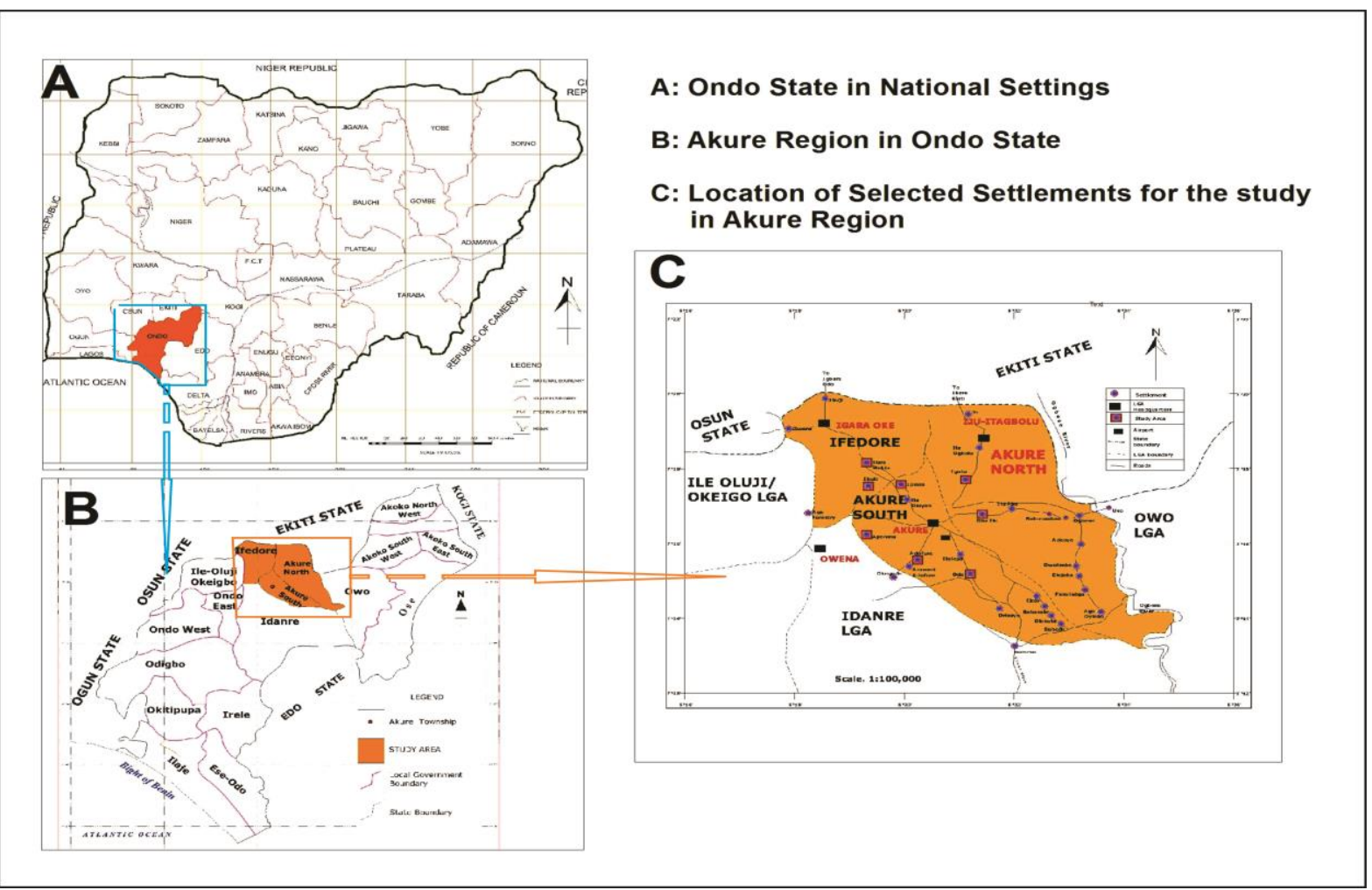

Figure 1. Locational Maps of the Study Area - Akure Region

Source: Ondo State Ministry of Physical Planning and Development, Akure (Updated by Author, 2019)

\section{Results}

\subsection{Urban Growth Dynamics and Land Use Classifications in Akure Region between 1985 and 2014}

Figures 2 shows the classification of land use in Akure region as at 1986. As revealed in the figure, only 5.1\% (6384 ha.) of the land area in the region were developed while $64.53 \%$ (80796 ha.) were covered with thick vegetation and $30.33 \%$ (37977 ha,) already cultivated and covered with light vegetation. Just about 56 hectares $(0.04 \%)$ were covered by water. This expression simply show that there was a small compact urban area with low level of development in the region as at 1986. 

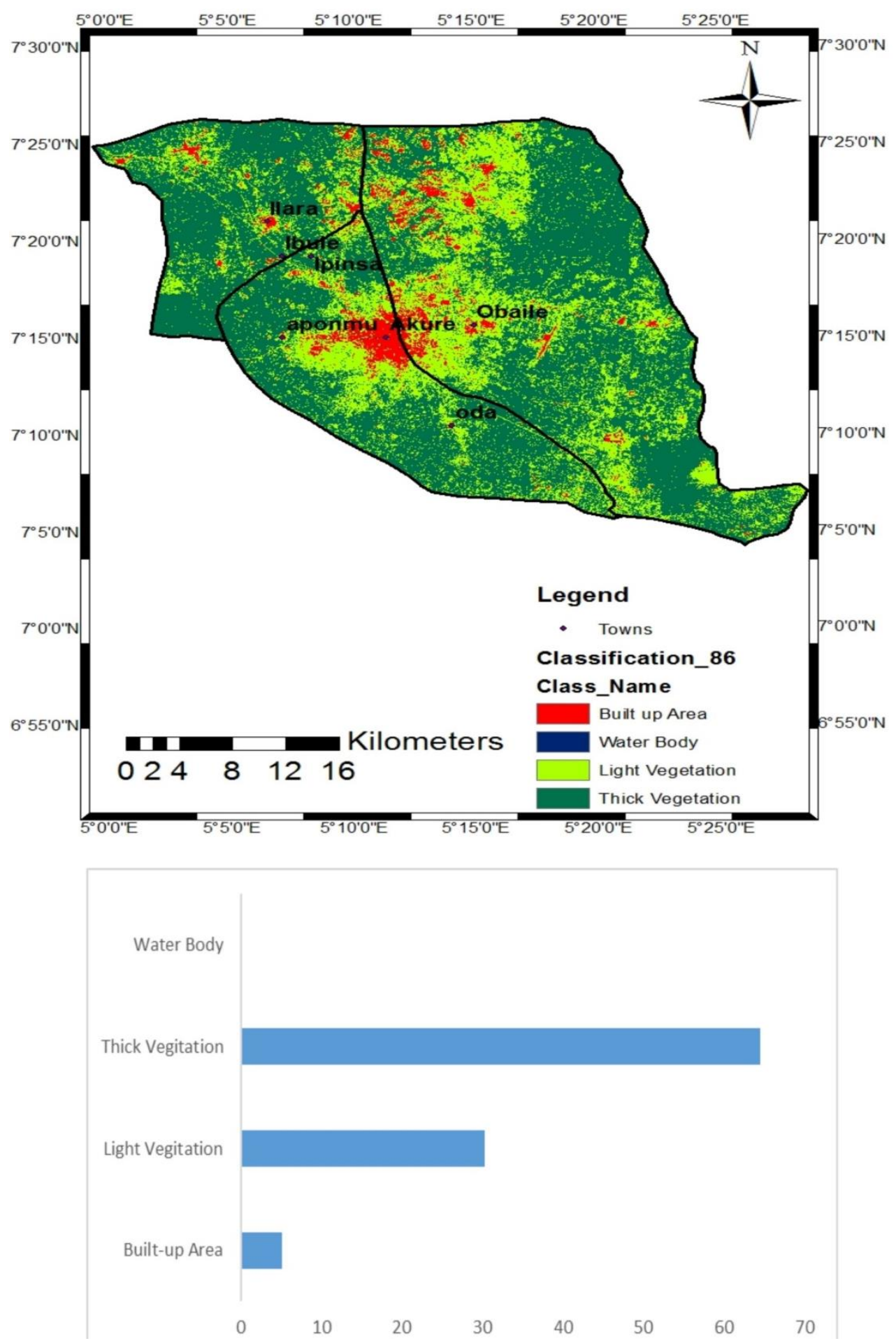

Figure 2. Land use classification and percent trend in Akure Region in 1986 (Landsat 4 TM 1986)

The percentage of built-up area and light vegetation in 2002, as shown in Figure 3, had increased to 16.63\% $(20,885$ ha.) and $55.06 \%$ (68,940 ha.) respectively while the thick vegetation was depleted considerably to $26.34 \%$ $(32,978$ ha.). This was a result of population increase in the region which necessiated further development and expansion through building constructions and provision of public facilities. 

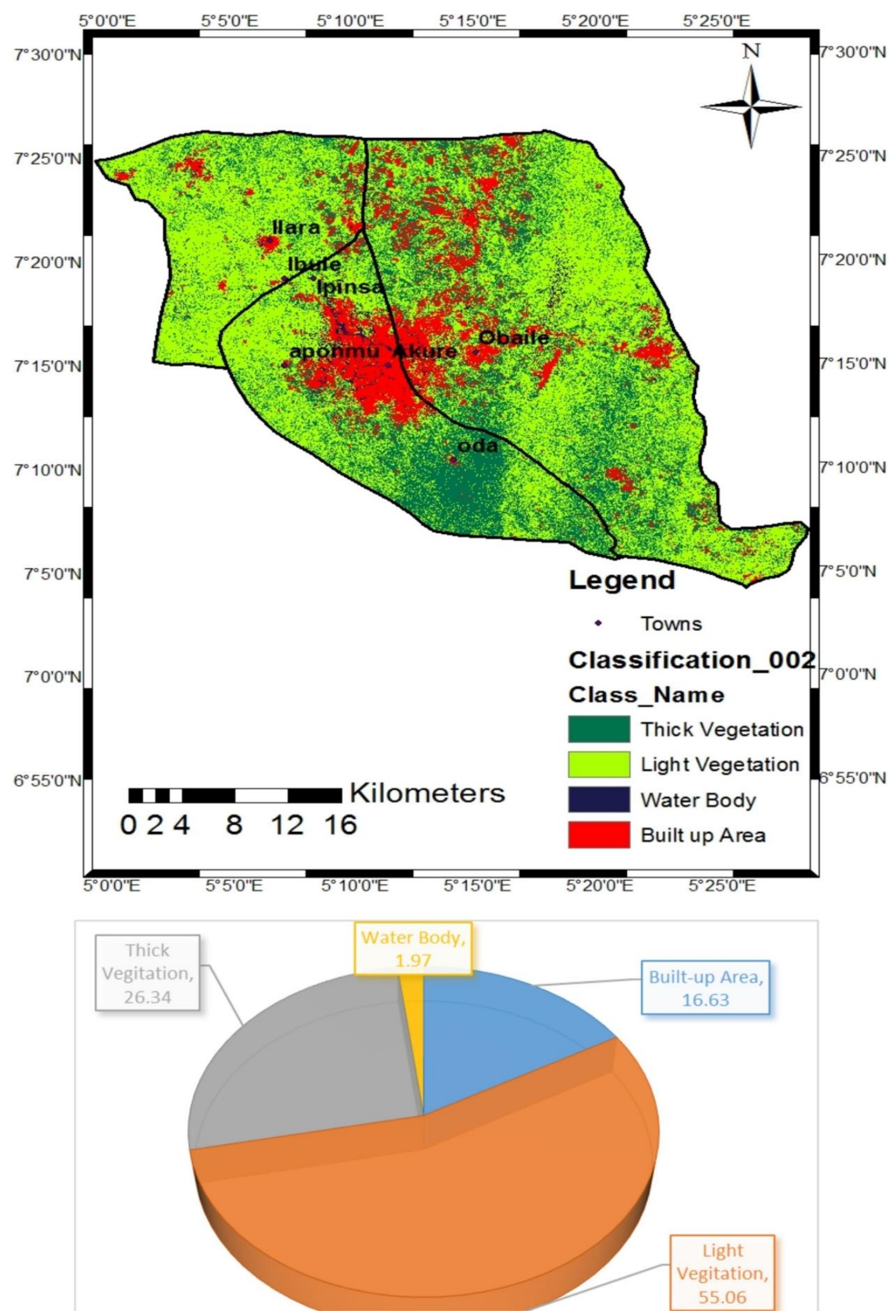

Figure 3. Land use classification and percent trend in the Akure Region in 2002 (Landsat $7 \mathrm{ETM}^{+}$2002)

Figures 4 shows further depletion in the thick vegetation to $15.18 \%$ (19,002 ha.) with increasing percentage in the built-up area and light vegetation to $18.36 \%$ (22,985 ha.) and $65.82 \%(82,415$ ha.) respectively. 


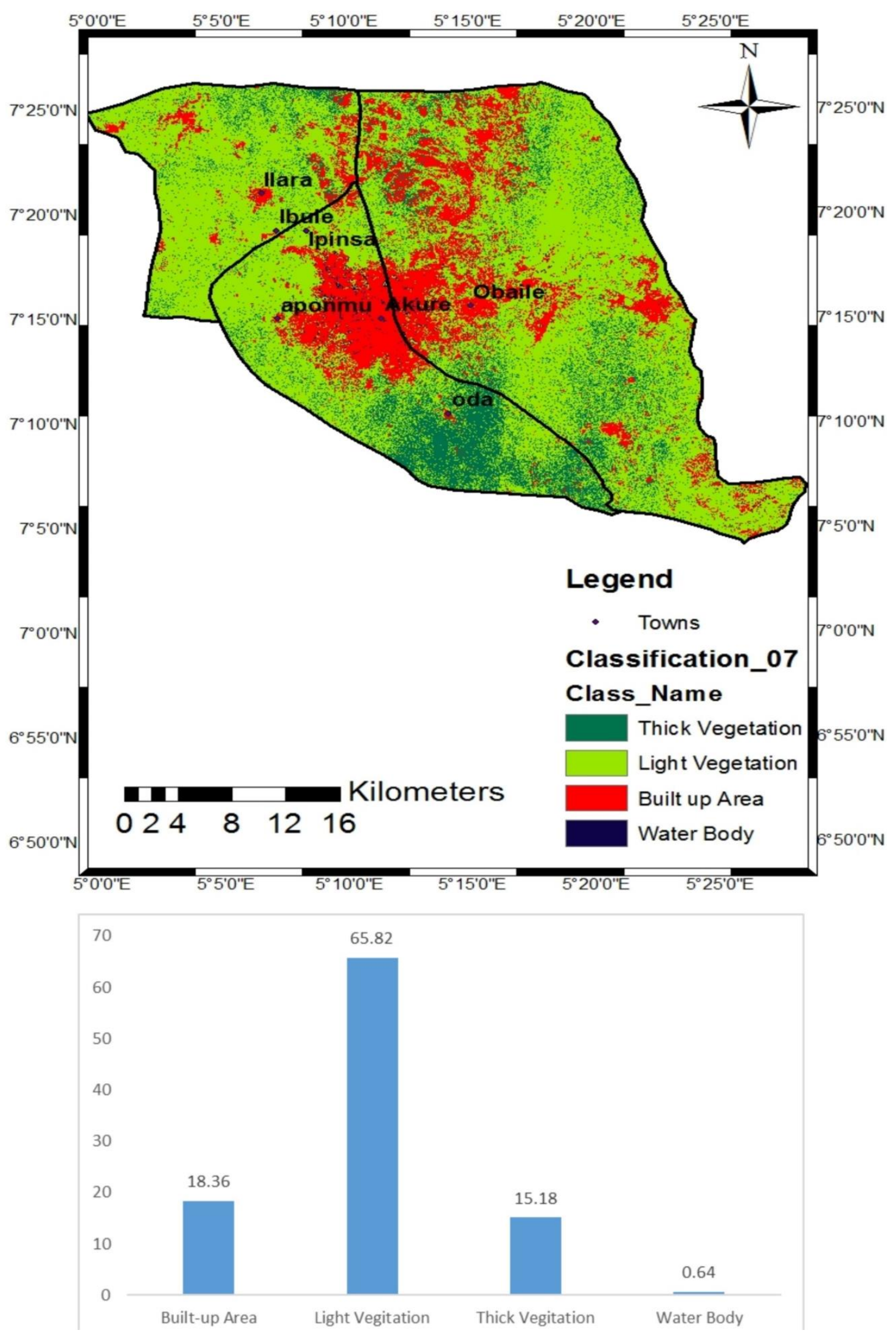

Figure 4. Land use classification and percent trend in Akure Region in 2207 (Landsat 7 ETM $^{+}$2007) 
Figures 5 illustrate LULC classifications in 2014 with further increase in the built-up area from $18.36 \%$ in 2007 to $26.33 \%$ in 2014 while light vegetation was depleted from $65.82 \%$ in 2007 to $57.51 \%$ in 2014 . This was a result of further increase in building construction and urbanization leading to conversion of land uses in the area.
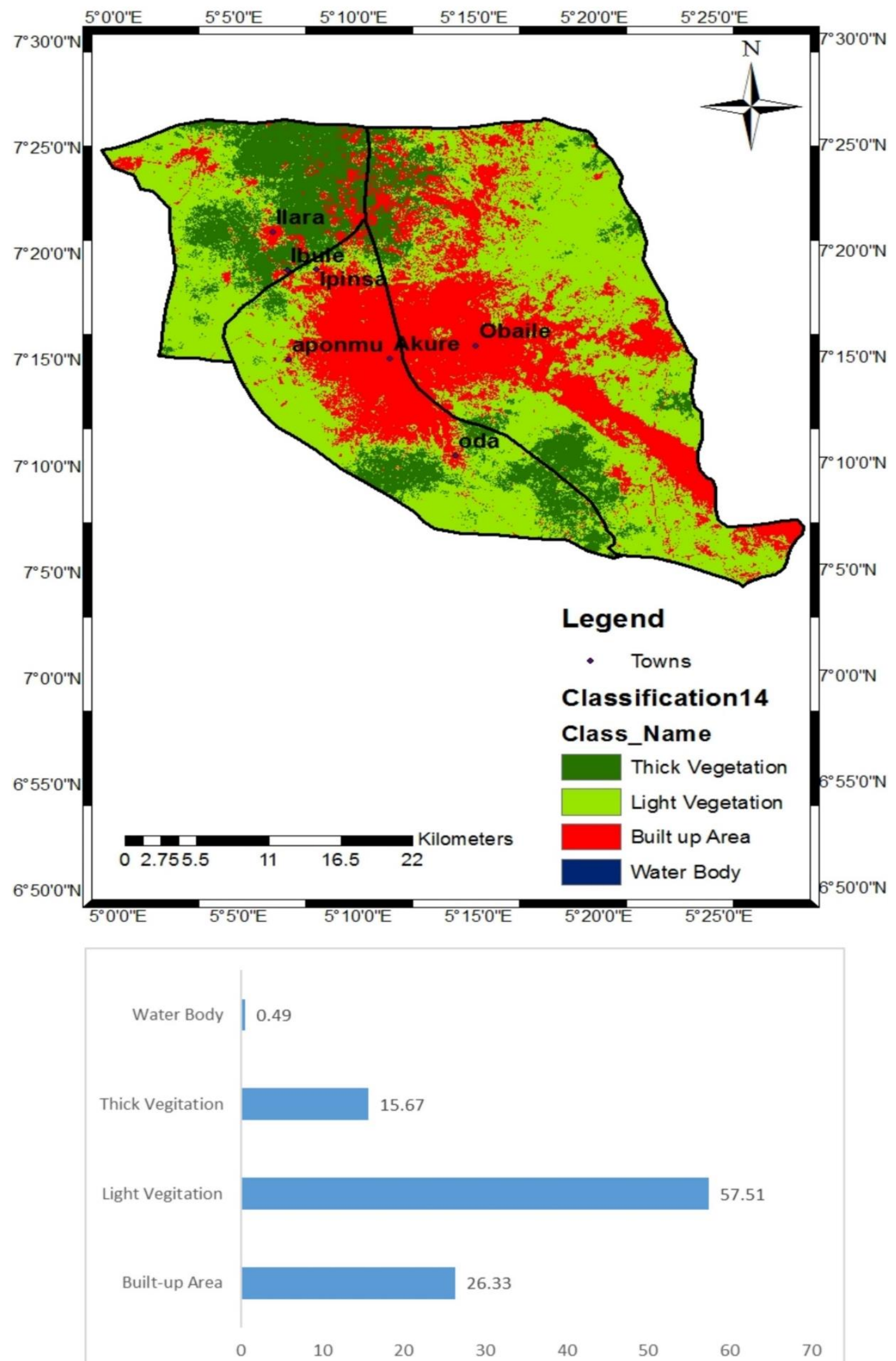

Figure 5. Land use classification and percent trend in Akure Region in 2014 (Landsat OLI 2014) 
3.2 LULC Change Trend and Agricultural Land use Depletion between 1985 and 2014

Table 1. Trend Analysis of Land Use and Land Cover Change in Akure Region (1985 - 2014)

\begin{tabular}{lrrrrrr}
\hline \multicolumn{1}{c}{ LULC } & \multicolumn{2}{c}{$\mathbf{1 9 8 6 - \mathbf { 2 0 0 2 }}$} & \multicolumn{2}{c}{$\mathbf{2 0 0 2} \mathbf{- 2 0 0 7}$} & \multicolumn{2}{c}{$\mathbf{2 0 0 7 - 2 0 1 4}$} \\
Classifications & $\begin{array}{r}\text { Difference in } \\
\text { Area (ha.) }\end{array}$ & $\begin{array}{r}\text { Difference in } \\
\text { Area (\%) }\end{array}$ & $\begin{array}{r}\text { Difference in } \\
\text { Area (ha.) }\end{array}$ & $\begin{array}{r}\text { Difference in } \\
\text { Area (\%) }\end{array}$ & $\begin{array}{r}\text { Difference } \\
\text { Area (ha.) }\end{array}$ & $\begin{array}{r}\text { Difference in } \\
\text { Area (\%) }\end{array}$ \\
\hline Built-up Area & 14441 & 11.53 & 2160 & 1.73 & 11318 & 9.04 \\
Thick Veg. & -47818 & -38.19 & -13976 & -11.16 & -1379 & -1.11 \\
Light Veg. & 30963 & 24.73 & 13475 & 10.76 & -9740 & -7.78 \\
Water Body & 2413 & 1.93 & -1658 & -1.33 & -199 & -0.15 \\
\hline
\end{tabular}

Sources: Landsat Imageries (1986, 2002, 2007 and 2014)

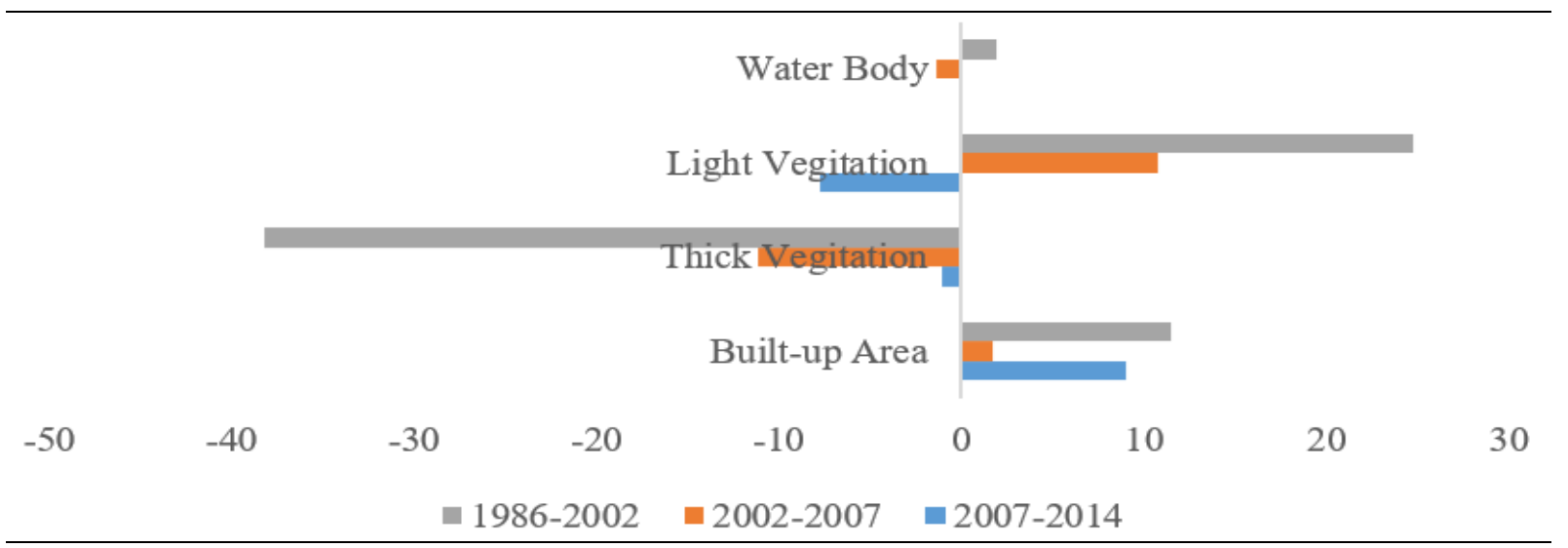

Figure 6. Akure LULC classification and change trend (Landsat Imageries 1986, 2002, 2007 and 2014)

3.3 Twenty year Prejection Model for Akure Future Expansion (2014 - 2034)

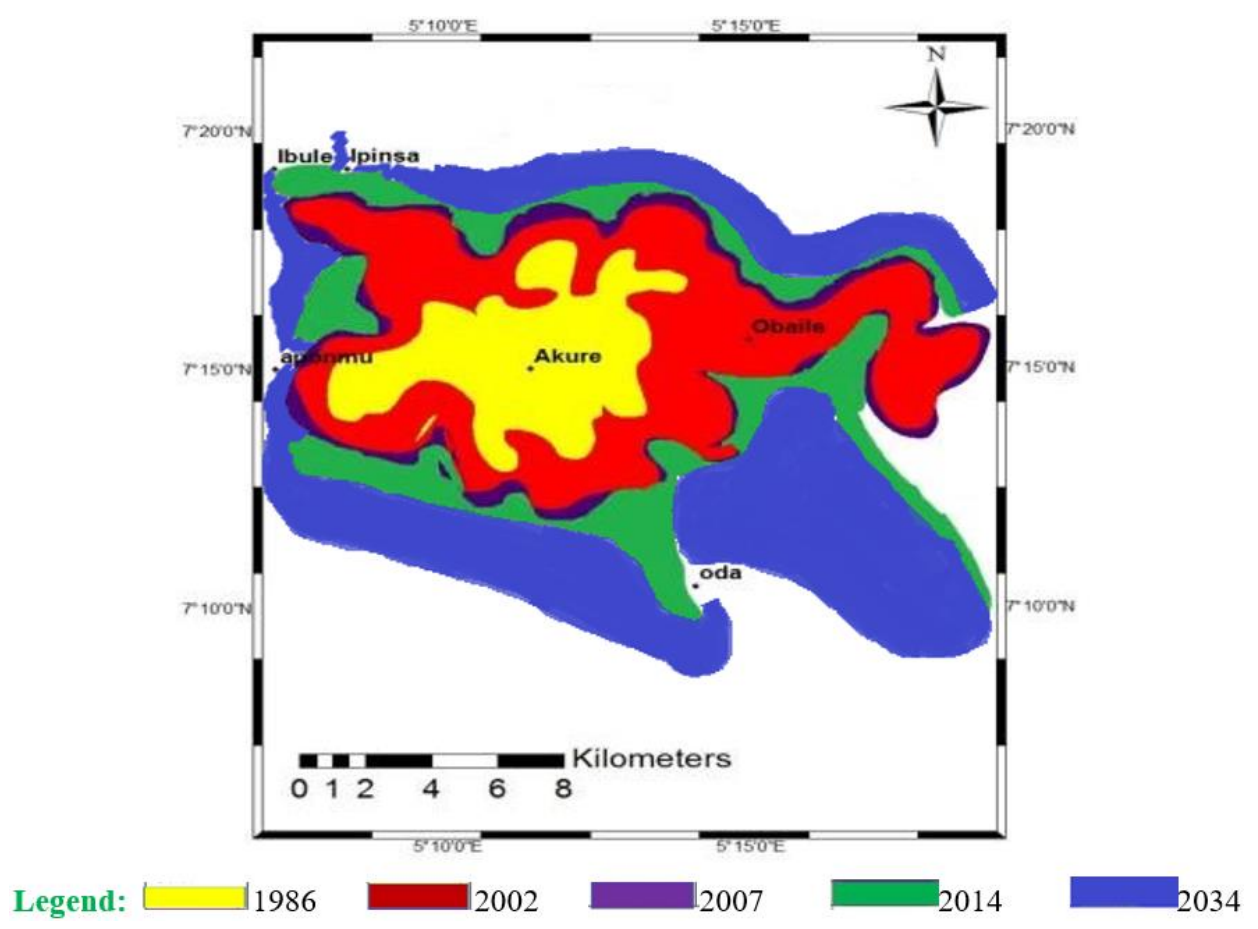

Figure 14. Graphical trend analysis of built-up areas \& prediction to 2034 (Landsat Imageries 1986, 2002, 2007, 2014) 
Table 2. Change Pattern in Built-up area from 1985 - 2014 and Projection to year 2034

\begin{tabular}{lrrr}
\hline Year of Observation & Growth Area (ha.) & Cumulative Area (ha.) & Percentage Area \\
\hline 1986 & 6383.65 & 6383.65 & 5.10 \\
2002 & 20825.33 & 27208.98 & 16.63 \\
2007 & 22984.57 & 50193.55 & 18.36 \\
2014 & 32969.15 & 83162.70 & 26.33 \\
2034 (Projected) & 66881.02 & 150043.72 & 53.41 \\
\hline
\end{tabular}

Source: Landsat Imageries (1986, 2002, 2007 and 2014)

3.4 Impact of Urban Growth Dynamics on LULC Change in the Study Area

Table 3. Kruskal-Wallis (H) Result on Impact of Urban Growth Dynamics on LULC Change in Akure

\begin{tabular}{lrrrrr}
\hline Variables Association & $\chi^{\mathbf{2}}$ Calculated & $\chi^{\mathbf{2}}$ Tabulated & Df & P-value & Decision \\
\hline IMPACT vs. POPDEN & 14.887 & 9.488 & 4 & 0.005 & $\mathrm{~S}$ \\
IMPACT vs. ESTPLOT & 49.141 & 9.488 & 4 & 0.000 & $\mathrm{~S}$ \\
IMPACT vs. NATDIS & 5.854 & 9.488 & 4 & 0.210 & $\mathrm{NS}$ \\
IMPACT vs. ENVQLTY & 6.081 & 9.488 & 4 & 0.193 & $\mathrm{NS}$ \\
IMPACT vs. CRIMRAT & 50.967 & 9.488 & 4 & 0.000 & $\mathrm{~S}$ \\
IMPACT vs. REASON & 17.406 & 9.488 & 4 & 0.002 & $\mathrm{~S}$ \\
IMPACT vs. FEATURE & 6.669 & 9.488 & 4 & 0.154 & $\mathrm{NS}$ \\
IMPACT vs. SETPAT & 18.366 & 9.488 & 4 & 0.001 & $\mathrm{~S}$ \\
IMPACT vs. DISTANC & 11.510 & 9.488 & 4 & 0.021 & $\mathrm{~S}$ \\
IMPACT vs. ENGAGR & 4.221 & 9.488 & 4 & 0.377 & $\mathrm{NS}$ \\
IMPACT vs. INTAGR & 13.979 & 9.488 & 4 & 0.007 & $\mathrm{~S}$ \\
IMPACT vs. CBOs & 9.770 & 9.488 & 4 & 0.044 & $\mathrm{~S}$ \\
\hline
\end{tabular}

$\mathbf{S}=$ Significant, $\mathbf{N S}=$ Not Significant at 0.05 alpha levels. Grouping Variable: Impact of expansion (IMPACT)

Source: Field Survey, 2014

Table 4. Analysis of Variance (ANOVA) Summary

\begin{tabular}{lllllllllll}
\hline & & & & \multicolumn{5}{c}{ Change Statistics } \\
\cline { 5 - 9 } Model R & $\mathrm{R}^{2}$ & Adjusted $\mathrm{R}^{2}$ & $\begin{array}{l}\text { Std. Error of } \\
\text { the Estimate }\end{array}$ & $\begin{array}{l}\text { R Square } \\
\text { Change }\end{array}$ & F Change & df1 & df2 & F Change \\
\hline 1 & $.601^{\mathrm{a}}$ & .361 & .472 & 1.091 & .601 & 4.444 & 8 & 347 & .001 \\
\hline
\end{tabular}

Predictors: (constant), POPDEN, ESTPLOT, REASON, INTERGR, CRIMRAT, SETPAT, DISTANC, CBOs.

Dependent Variables: Impact of expansion (IMPACT)

Source: Field Survey (2014)

Table 5. Impacts of Akure Urban Growth on LULC change in the adjoining Settlements

\begin{tabular}{lrr}
\hline Impacts of the Expansion & Frequency & Percentage \\
\hline Incessant Crime & 7 & 5.4 \\
Conversion of farmlands to other land uses & 31 & 24.0 \\
Lack of labour for farm work & 80 & 62.0 \\
Congestion on few available facilities & 9 & 7.0 \\
Others & 2 & 1.6 \\
Total & $\mathbf{1 2 9}$ & $\mathbf{1 0 0 . 0}$ \\
\hline
\end{tabular}

Source: Field Survey, 2014. 


\section{Discussion}

\subsection{Urban Growth Dynamics and Land Use Classifications in Akure Region between 1985 and 2014}

The inference deduced from the analysis on land use classification, as shown in section 3.1, is the increased trend of urban expansion as revealed by the steady upsurge in the built-up area. The drastic reduction in the percentage area covered by thick vegetation shows there was a phenomenal growth within the studying period. For instance, the built-up area increased by $22.3 \%$ between 1986 and 2014 which is the result of much encroachment into agricultural, rocky and undulating land areas for the purpose of building construction, quarry, blasting and mining activities that took place at one time or the other in the region. It was observed, however, that the economic situation in the early years of the millenium favour individuals, government and establishments to embark on massive developments. This accounted for the tremendous increase in the built-up areas, which resulted in massive physical expansion of the region at the expense of farmlands being depleted. Besides, Akure gained much influx of people seeking greener pastures being the state capital while the discovery of bitumen in the state attracted many investors and other immigrants from far and near distant areas around the city. The residency of these investors and other immigrants have their base in Akure. The administrative status of the city and the concentration of various establishments like government ministries, several housing estates, Ondo State Oil Producing Area Development Commission (OSOPADEC) secretariat, Federal University of Technology, Akure (FUTA), banking institutions and finacehouse regional headquarters, among others were centres of consideration for this attraction. With this, the thick vegetation, meant for agricultural activities, was heavily depleted and considerably reduced by $50.46 \%$ within the period of study.

Further enquiry was made to probe into the direction of growth of the city with a view to determining the level of depletion at different path of the region. For instance, between 1985 and 2002, the growth traversed more towards the northern and the eastern parts of the region than any other direction. These areas were earmarked for the location of Government Residential Areas (GRAs) where most of the government parastatals and ministries were situated. The construction of Ilesha-Akure-Owo express route in the north-eastern part of the city was another notable factor that plays prominent role in attracting people to that area. Thereafter, the direction of growth shifted to other areas at different time; probably, where cheap lands and good topography that favour construction are readily available. The location of Federal University of Technology, Akure (FUTA) has much influence in attracting huge population into the north-western part of the city. Most staff of the institution and students prefer living around the vicinity of the school, thereby making the growth toward that direction to be institutional attraction. Currently, the growth around this institution has almost captured Ipinsa and Ibule (the two nearest proximate settlements). Students finds cheaper accommodation in those two communities, while members of staff of the institution and some other people from the city find cheap lands to build houses and hostel accommodation for students. This and other important developments that parade the city are clear evidences of changes in land use and land cover at different epoch that have responsible to massive depletion of farmlands at the suburbs.

\subsection{LULC Change Trend and Agricultural Land Use Depletion between 1985 and 2014}

Trend analysis of land use and land cover (LULC) change pattern from 1986-2002, 2002-2007 and 2007-2014 are shown in Table 1 and Figure 6. The table and the figure revealed appreciable increase in the built-up area as indicated in its positive index values all though the study period as well as light vegetation (except in 2007-2014 when the rate of depletion begin to have negative index). The thick vegetation have negative index all through showing rapid depletion throughout the epoch. The thick vegetation, meant for agricultural purposes like farming, forestry, animal conservation, among others, was rapidly depleted as it gives way to variuos constructions, lumbering, minning and other developmental activities at one time or the other in the region. Figures 7-13 show some of the facilities provided at different locations in the region within the period of study.

Figures 7, 8 and 9 were located mainly in high residential density as well as transitional zones in Akure which made significant alterations in the physical landscape, traditional and socio-economic lifestyles of residents in the city. Meanwhile, people whose properties were acquired at the city core and transition zone where these facilities are located were indirectly forced to relocate to the peripheries and the suburbs where cheap lands are presumed to be available. 


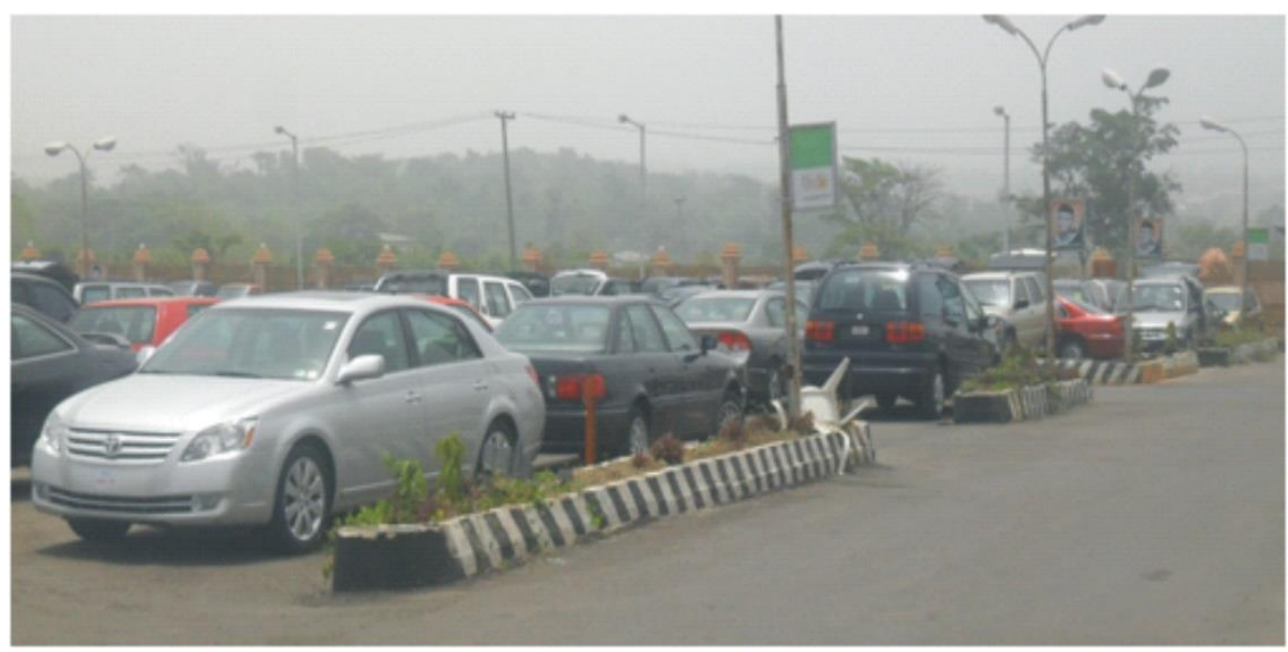

Figure 7. Auto-mart Station along Akure-Owo Express Way, Akure (Field Survey, 2014)

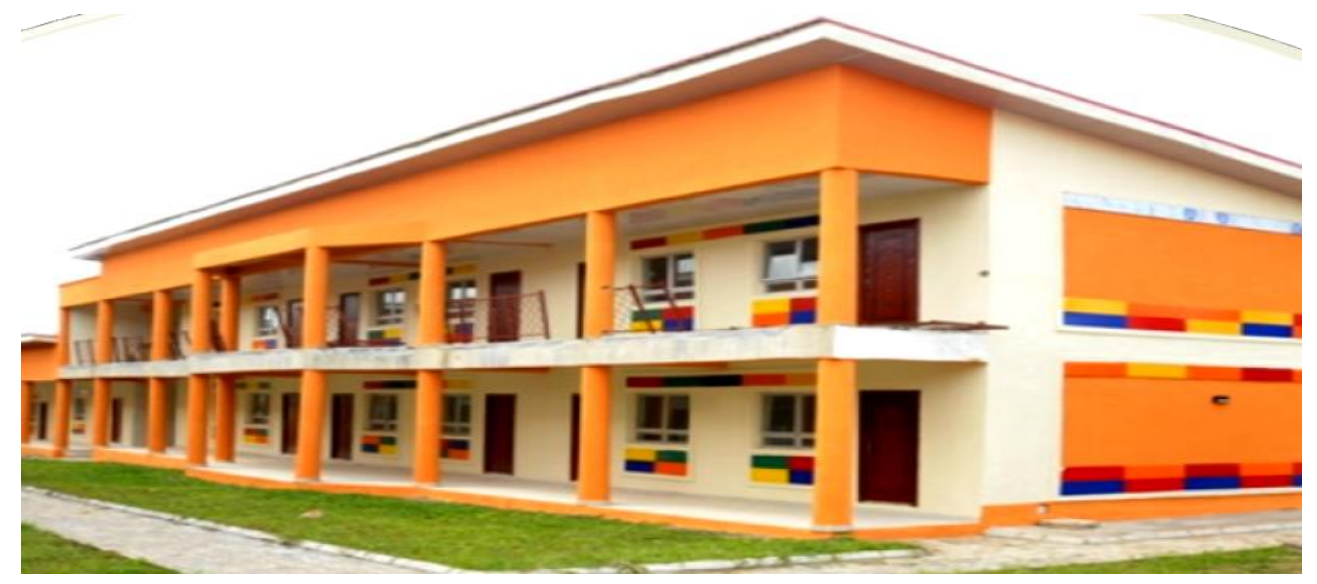

Figure 8. Template of Mega Schools built in different parts of the region (Field Survey, 2014)

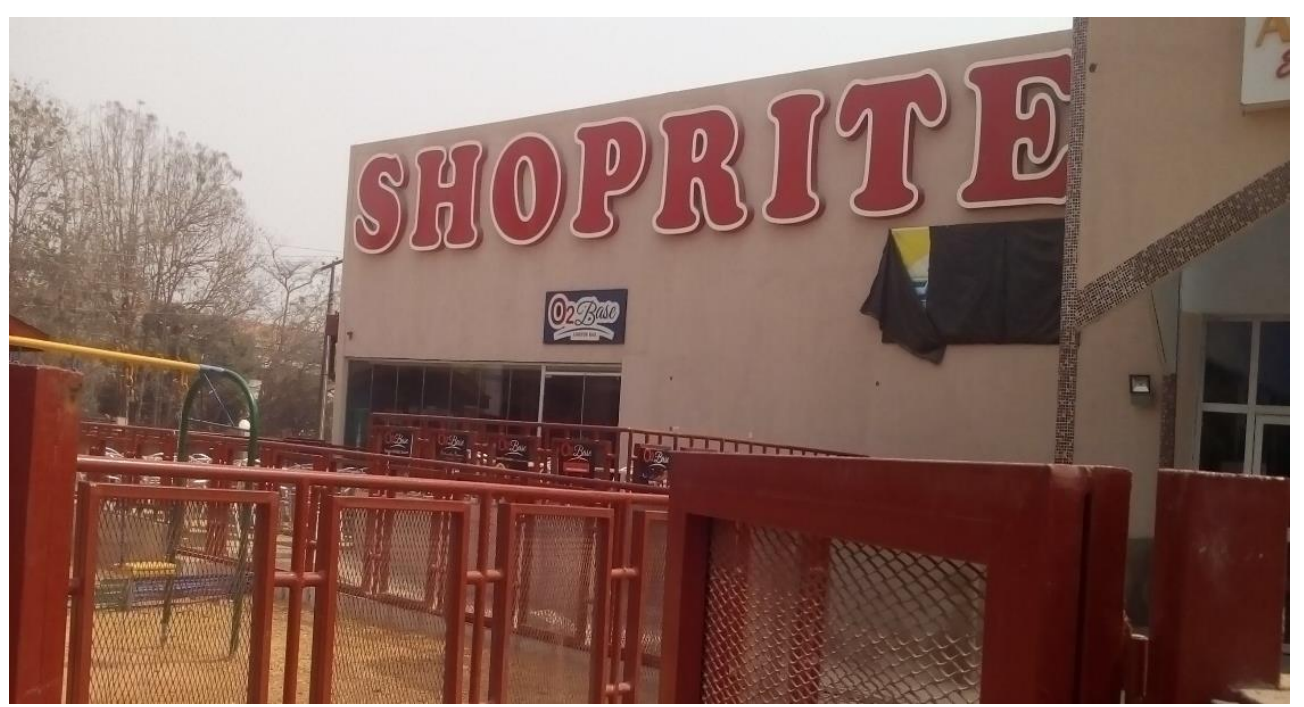

Figure 9. Shoprite Supermarket at Alagbaka in Akure Periphery (Field Survey, 2015)

Figure 10 is a sample of such new buildings constructed at the urban peripheries and the suburbs which were, in most cases, occupied before completion. Figure 11 is the establishment of Staff Training Institute at Ilara-mokin (a suburb of Akure) by the Ondo State Government due to its proximity to the city. It was primarily aimed at decongesting the state capital and for the purpose of regional development scheme to upgrade the suburb. Figure 
12 is the dualization project of Akure-Obaile road which was motivated by the daily migration of high influx from the community (Oba-ile) to the city (Akure). Most residents of the community are either working in public or private establishment or engaged in business transactions in Akure. Thus, they ply the route every day thereby generating high traffic flow along the axis on daily basis. The construction therefore became necessary to easy vehicular movement congestion along the axis. Figure 13 is Sunshine Estate which was constructed by the Ondo State Government (ODSG) to provide affordable site-and-service residential facilities for people who could not secure accommodation or purchase land for building construction in the city center.

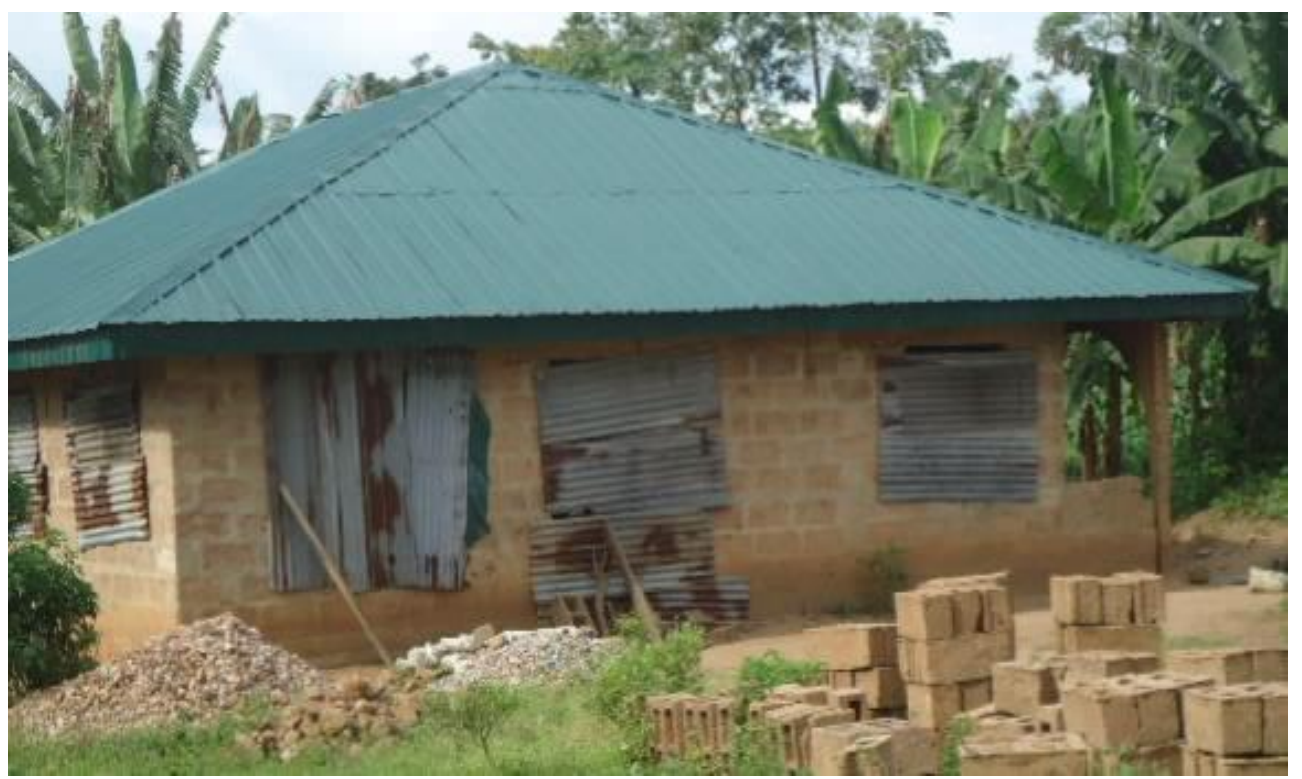

Figure 10. Sample of most newly constructed buildings in the Urban Periphery (Field Survey, 2015)

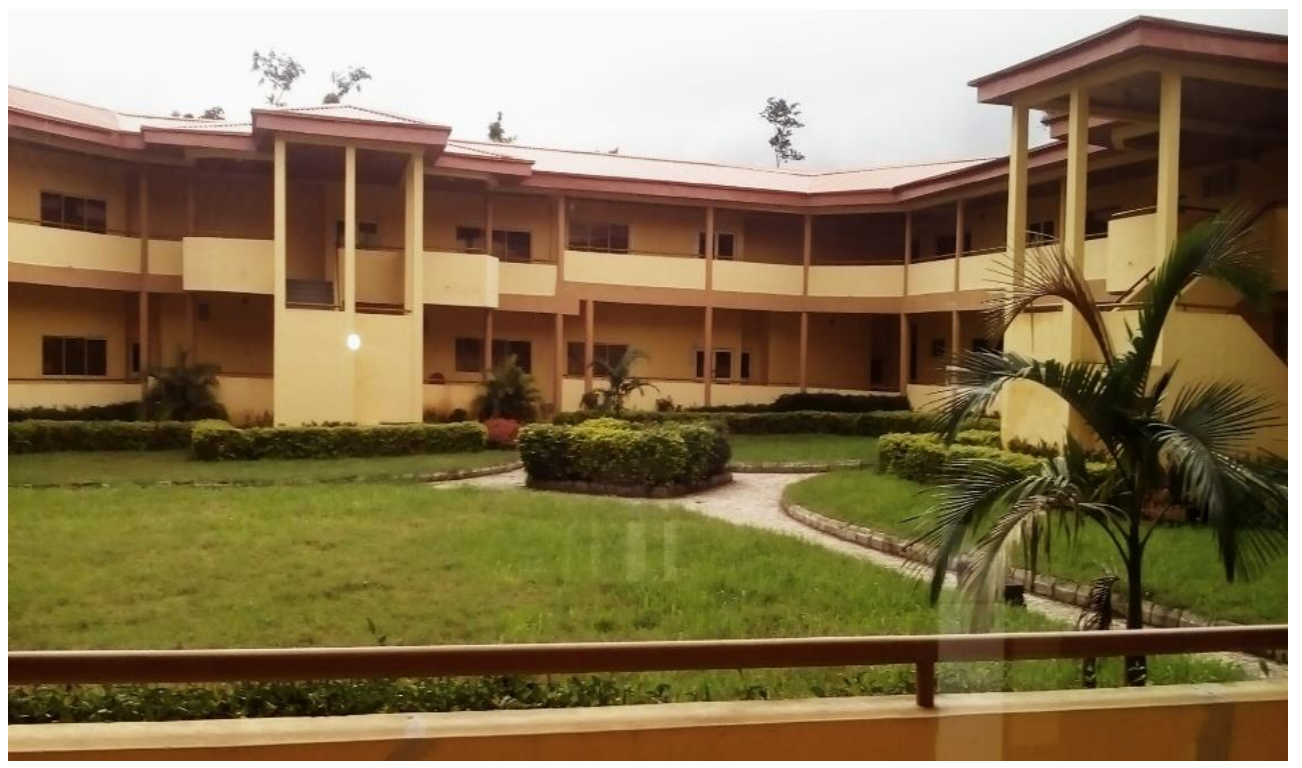

Figure 11. Ondo State Staff Development Training Institutes at Ilara-Mokin (Field Survey, 2015) 


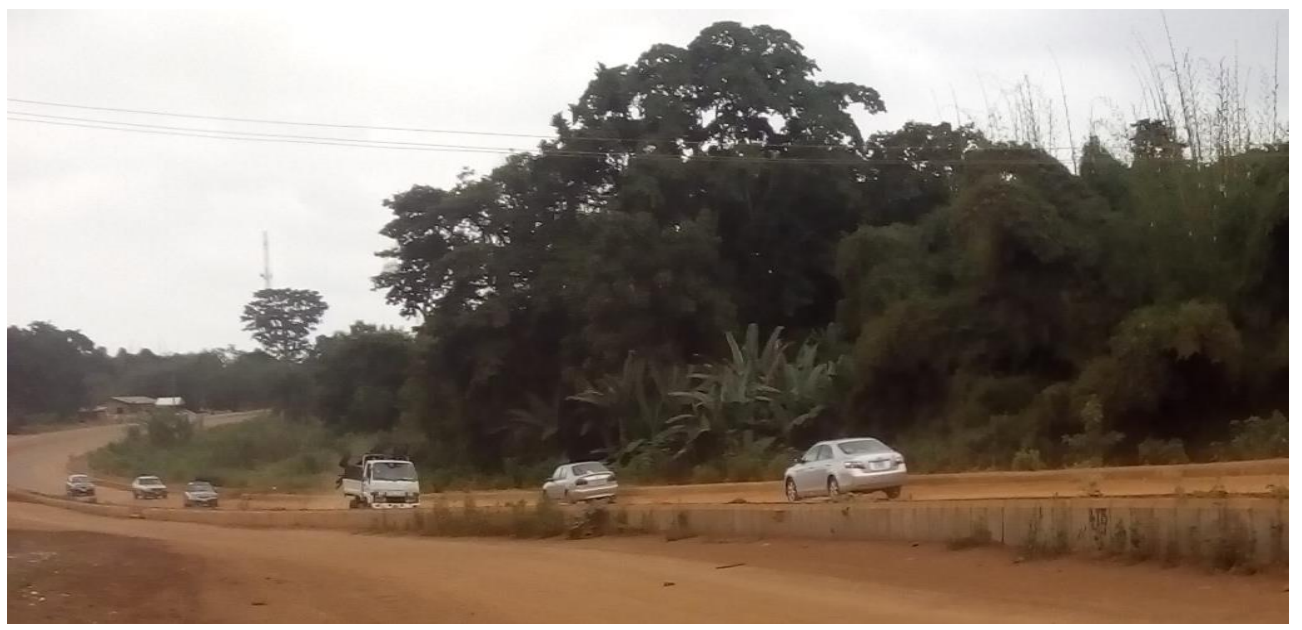

Figure 12. The Akure-Obaile Road Dualisation Project (Field Survey, 2015)

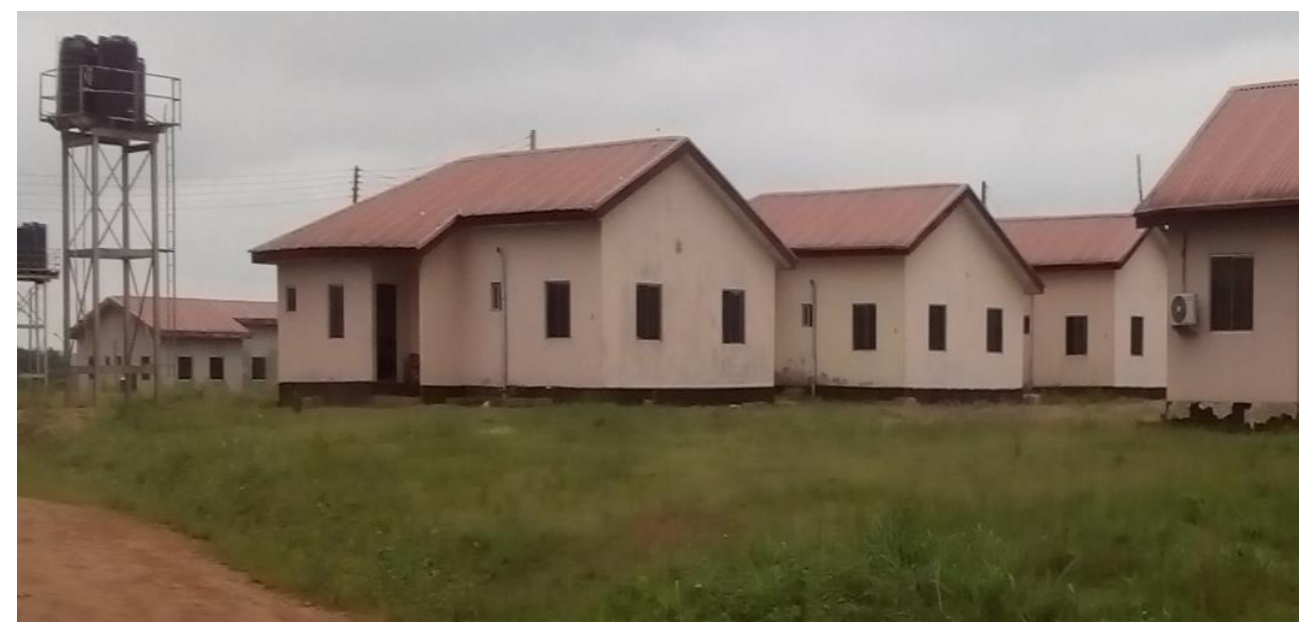

Figure 13. Sunshine Housing Estate along Ilesha-Akure Road, Ibule-soro (Field Survey, 2015)

With all these efforts made towards achieving facility provision, decongestion of state capital and regional development policy of the state government, much lands at the suburbs meant for various agricultural activities are heavily depleted while able bodies that are used as farm labour in the rural communities are lost on regular basis in quest for salary job at the city center.

\subsection{Twenty year Prejection Model for Akure Future Expansion (2014 - 2034)}

Consequent upon findings made in this study, future prediction was modeled with the aid of Markov Chain technique to guide policy makers in the management of land use activities in Akure and its environs. The prediction was strictly focused on built-up areas based on the trend of growth dynamics observed in the study area from 1985-2014. The land expansion was projected at 66,881.02 hectares, using the 3.6\% growth rates adopted by Oyinloye (2010) in the exponential growth model of Hofste and Brussels (2002). This analysis is computed and display in Table 2. Figure 14 illustrates the result of the growth generated from the interpolation and overlaying of Figures 2-5 and the projected land area for future expansion as analyzed in Table 2. Thus, it represents the graphical trend analysis of changes observable in the built-up areas which depicts the extent and direction of growth of Akure region over a period of three decades (1985-2014) and its prediction for another two decades (2014-2034). By then, there is possibility of Akure becoming a full grown conurbation when it would have subsumed most of its proximate communities like Ipinsa, Ibule, Ilara, Awule, Jegele, Igoba, Isinigbo, Adofure, Oda and Oba-ile, among others. This is a clear indication of the dynamism in the growth of the city and massive encroachment on agricultural lands in the adjoining communities. No doubt, the consequence on paucity of food production and deprivation on the general livelihoods of rural dwellers is evident. 


\subsection{Impact of Urban Growth Dynamics on LULC Change in the Study Area}

The Chi square value in Kruskal-Wallis (H) statistical test conducted, as shown in Table 3, determines the significant association of each variable of urban growth dynamics with the impact (IMPACT) on LULC change in Akure metropolis. Of all the twelve variables examined against the IMPACT predictor, four do not have significant association (or negative impact) at 0.05 alpha levels. These include frequency of natural disaster (NATDIS), environmental quality (ENVQLTY), emergence of features/facilities (FEATURE), and engagement in urban agriculture (ENGARG). These four variables were dropped in multiple regression analysis that was latter computed in Table 4 to determine the overall impact of the expansion. From the table, the significant variables examined in the regression model to predict the impact was given by the coefficient of determination $\left(R^{2}=0.361\right)$. This implies that $36.1 \%$ of factors responsible for the impact on LULC change are accountable by variables investigated in the model. This was further corroborated by the high value of F-change (4.444) in the model which is greater than the T-test value (2.31 and 3.36) at both 0.05 and 0.01 alpha levels respectively. The implication of this analysis shows that the growth dynamics experienced in the region emanate from Akure city. The peripheral developments in the city is primarily residential; hence, residents travel long distances to the city centre for their daily transactions and engagements which often generate traffic congestion, thereby causing much travel time and time wasting on regular basis.

Evidences attesting to further impacts of the expansion on adjoining settlements are shown in Table 5. For instance, $24 \%$ of the 129 responses received from the eight randomly selected settlements around the city attested to excessive conversion of their farmlands to other land uses while $62 \%$ affirmed the lack of labour to work on their farms. The overall effect of these on food security in the region is convincingly high if the situation continues.

\section{Conclusions}

The study has shown the pattern of expansion experienced in the city over three decades with attendant effects on agricultural land use around the city. There was serious encroachment into green lands in the contiguous settlements occasioned by haphazard growth and irregular land use conversions. This scenario was linked with much influx of people into the city, being the state capital and, more importantly, the discovery of bitumen in the state which attracted much investors and other immigrants. Its administrative status and concentration of establishments were the key indices for this attraction. Consequent upon this, the thick vegetation was massively encroached to allow developments and expansion in various directions into the adjoining communities. The impacts of this on the agricultural activies in the communities are enoumous. Aside the conversion of lands used for agricultural purposes, most able bodies migrate from rural areas to urban centres in quest of greener pasture; hence, there is dearth of labour to work in the farms. This, in no doubt, has much to tell on food security in the region if nothing reasonable is done to curtail the incidence. In view of these, the study suggest proper check on land acquisition and allocation procedures for various uses with a view to controlling the menace of incompatible use of lands. To achieve this, ministries in-charge of land management should employ resourceful control measures over private and public lands through zoning and effective monitoring strategies for sustainable development. Besides, urban agriculture should be given a place of priority as a measure to enhance food security in the region. Therefore, lands meant for agricultural activities should not be unduly intruded in the name of growth and development. Alternatively, vertical expansion can be encouraged in the form of story buildings, high scrappers, and the likes with a view to reducing the rate of land consumption.

Generally, urban growth induced by unguided development into rural lands is taking serious tolls on the socio-economic lifestyles of rural dwellers. As it has been observed in the study and other related readings, the effects are enormous than what can be handled with levity without giving adequate and prompt attention. Efforts are to be asserted at local, state and federal levels to mount up improved urban planning strategies on this issue. The aim is to promote sound and sustainable environment, considering the source of livelihoods of residents at the proximate communities which are mostly affected by the indiscriminate urban expansion. Therefore, all existing policies on urban growth monitoring should be given proper review while new strategies that will match-up with the current trend of development and growth be postulated on appropriate models for optimum results.

\section{Acknowledgment}

The financial support of the management of the Federal University of Technology, Akure in carrying out this research is quit appreciated. I also recognize the professional advice of Dr. F.O Akinluyi and Mr. Femi Adeyeri of Remote Sensing Department, Federal University of Technology, Akure. 


\section{References}

Adesina, F. A., Siyanbola, W. O., Okelola, F. O., Pelemo, D. A., Ojo, L. O., \& Adegbulugbe, A. O. (1999). Potential of Agro-forestry for climate change mitigation in Nigeria: Some preliminary estimate in Glo. Ecol. Biogeography Lett., 8, 163-173. https://doi.org/10.1046/j.1365-2699.1999.00122.x

Akinbode, O. M., Eludoyin, A. O., \& Fashae, O. A. (2007). Temperature and relative humidity distributions in a medium-size administrative town in South-western Nigeria; Journal of Environmental Management. Retrieved September 15, 2013, from https://doi.org/10.1016/j.jenvman.2007.01.018

Balogun, A. A., Balogun, I. A., Adefisan, A. E., \& Abatan, A. A. (2009). Observed characteristics of the urban heat island during the harmattan and monsoon in Akure, Nigeria; $8^{\text {th }}$ Conference on the Urban Environment. AMS 89 $9^{\text {th }}$ Annual Meeting, 11-15 January. Retrieved August 30, 2012 from http://ams.confex.com/ams/pdfpapers/ 152809.pdf

Balogun, I. A., Adeyewa, D. Z., Balogun, A. A., \& Morakinyo, T. E. (2011). Analysis of Urban Expansion and Land Use Changes in Akure, Nigeria using RS and GIS techniques. Journal of Geography and Regional Planning, 4(9), 533-541.

Chellasamy, M., Chinnasamy, U., \& Ramaswamy, S. K. (2015). A neural-evidence pooling approach to predict urban sprawl using multi-temporal remote sensing data. International Journal of Geomatics and Geosciences, 5(3), 459-473.

Chen, H., Liang, X., \& Li, R. (2013). Based on a multi-agent system for multi-scale simulation and application of household's LUCC: A case study for Mengchavillage, Mizhi country, Shaanxi province. Springer plus 2 (Suppl. 1), S12. https://doi.org/10.1186/2193-1801-2-S1-S12

Hofstede, G., \& Brussels, B. (2002). Analysis of Urban Change and Spatial Pattern. International Institutes for Aerospace Survey and Earth Science (ITC), ILWIS Practical Manual (Chapter 20).

Houghton, R. (1994). The worldwide extent of land use change. Bioscience, pp. 305-313. https://doi.org/10.2307/1312380

Kaifang, S., Yun, Ch., Bailang, Y., Tingbao, X., Chang, H., Rui, L., Zuoqi, Ch., \& Jianping, W. (2016). Urban expansion and agricultural land loss in China: A multiscale perspective. Sustainability (MDPI), 8, 790. https://doi.org/10.3390/su8080790

Kufoniyi, O. (1998). Towards 3D GIS for Efficient Management of Urban Environment; Proceeding of the Technical Session of the $32^{\text {nd }}$ AGM and Conference of the Nigerian Institution of Surveyors, Uyo, 5-7.

Mirkatouli, J., Hosseini, A., \& Neshat, A. (2015). Analysis of land use and land cover spatial pattern based on Markov chains modelling. City, Territory and Architecture, 2(4), 1-9. https://doi.org/10.1186/s40410-015-0023-8

Murali, K. G. (2017). Urban sprawl and adverse impact on agricultural land: A case study on Hyderabad, India. Remote Sensing (MDPI), 9, 1136. https://doi.org/10.3390/rs9111136

National Population Commission (NPC, 1963, 1991 and 2006). National Population Census Reports.

Oduwaye, L. (2015). Urban Land Use Planning and Reconciliation. Inaugural Lecture Series 2015, University of Lagos, Nigeria.

Olofin, E. A. (2012). The challenges of desertification and its effects on physical planning in Nigeria. A paper presented at the $43^{\text {rd }}$ Annual Conference of the Nigerian Institute of Town Planners held at Women Development Centre, Abuja; November, 7-10.

Owoeye, J. O. (2016). Urban sprawl and changing land use pattern in Akure Region. Unpublished PhD Thesis, Ekiti State University, Ado-Ekiti, Nigeria.

Oyinloye, M. A. (2010). Spatial Analysis of Urban Growth in Akure, Nigeria; Unpublished PhD Thesis, Federal University of Technology, Akure, Nigeria.

Oyinloye, M. A. (2013). Geospatial Analysis of Urban Growth - The case of Akure, Nigeria. American Journal of Social Issues and Humanities, 3(4), 200-212.

Rimal, B. (2013). Urbanization and the Decline of Agricultural Land in Pokhara Sub-Metropolitan City, Nepal. Journal of Agricultural Science, 5(1), 54-65. https://doi.org/10.5539/jas.v5n1p54

UN Report. (2018). The State of World Population; United Nation Publication; New York: 76. 


\section{Copyrights}

Copyright for this article is retained by the author(s), with first publication rights granted to the journal.

This is an open-access article distributed under the terms and conditions of the Creative Commons Attribution license (http://creativecommons.org/licenses/by/4.0/). 